\title{
ANALISIS MAKNA GRAMATIKAL JOUKEN HYOUGEN TO DAN TARA DALAM DRAMA OKURIBITO
}

\author{
Siswoyo \\ 3122011369@mhs.dinus.ac.id \\ Universitas Dian Nuswantoro
}

\begin{abstract}
This thesis discusses the substitutions of to and tara conjunction terms of grammatical meaning occour in Okuribito drama. It aims to analyze the substitution of to and tara. The data analysis was conducted by using distributional qualitative method with syntactic and semantic design based on Suzuki Shinoru's theory. The results of reveal that to and tara conjunctions are mutually substitutable when they show the following meaning: general situation, habitual, hope, thought, and constancy. However, they are not mutually substitutable when they are used to show: assumption, permission, wish, action, intention and advice.
\end{abstract}

Keywords: Conditional Sentence, To Conjunction, Tara Conjunction, Substitution, Synonym.

Bahasa Jepang merupakan salah satu bahasa asing yang jumlah pembelajarnya banyak di Indonesia. Hal ini menunjukkan bahwa perkembangan bahasa Jepang di Indonesia sangat pesat. Akan tetapi, yang jadi pertanyaan adalah bagaimana para pembelajar dapat memahami serta menggunakan bahasa Jepang dengan baik dan benar. Diantara pembelajar tersebut, tidak sedikit yang mengalami kesulitan ketika mempelajarinya. Salah satu penyebabnya adalah bahasa Jepang memiliki banyak persamaan kosakata, sedangkan di dalamnya terdapat makna dan cara penggunaan yang berbeda-beda. Hal tersebut menyebabkan pembelajar sulit membedakan penggunaan kosakata yang benar. Demikian pula halnya dengan kalimat pengandaian atau jouken hyougen. Menurut buku Shokyuu o Oshieru Hito no Tame no Nihongo Bunpou Hando bukku (Matsuoka et al, 2000: 220), kalimat pengandaian dalam bahasa Jepang dapat diungkapkan menggunakan 4 konjungsi yaitu to, ba, tara, dan nara. Pada penelitian ini penulis hanya menganalisis konjungsi "to" dan "tara" karena kedua konjungsi tersebut memiliki kemiripan makna dan secara gramatikal juga dapat disubstitusi.

Kridalaksana (1983: 90) mendefinisikan konjungsi adalah "partikel yang digunakan untuk menggabungkan kata dengan kata, frase dengan frase, klausa 
Siswoyo, Analisis Makna Gramatikal Jouken Hyougen To dan Tara dalam Drama Okuribito

dengan klausa, kalimat dengan kalimat atau paragraf dengan paragraf”. Konjungsi “to” dan “tara” masuk dalam kelas kata sambung atau setsuzokujoshi (接続助詞) karena tidak dapat mengalami perubahan bentuk, dan tidak dapat berdiri sendiri sebagai satu kata (Sudjianto, 2004: 181). Konjungsi "to" dan "tara" berfungsi untuk menghubungkan anak kalimat dengan induk kalimat. Berikut ini adalah salah satu contoh penggunaan kalimat pengandaian dengan konjungsi "to" dan "tara" : (1) このボタンを押すと、お釣りがでます。(Minna no nihongo I,1998:190)

Kono botan o osuto, otsuri ga demasu.

'Kalau tombol ini ditekan, uang kembaliannya keluar'.

(2) 雨が降ったら、行きません。 (Shin Nihongo No Kiso I,1998: 206)

Ame ga futtara, ikimasen.

'Kalau hujan, tidak pergi'.

Konjungsi pada contoh kalimat 1 dan 2 mempunyai arti yang sama dalam bahasa Indonesia yaitu "kalau”, tetapi pada kalimat 1 dan 2 masih terdapat kerancuan apakah konjungsi yang ada pada contoh kalimat dapat disubstitusikan atau tidak dapat disubstitusikan. Berdasarkan hal tersebut, peneliti melakukan pra survey yang dilakukan terhadap 35 responden mahasiswa di Universitas Dian Nuswantoro Semarang yang telah belajar tentang penggunaan konjungsi "to" dan "tara". Hasil dari pra survey berdasarkan penilaian sistem akademik mahasiswa yang tidak lulus atau mendapatkan nilai D dan E sebanyak $88 \%$. Berdasarkan hasil tersebut, diperlukan kajian secara lebih mendalam tentang penggunaan konjungsi "to" dan "tara" dalam bentuk penelitian.

\section{METODE PENELITIAN}

Metode yang digunakan dalam menyusun penulisan ini adalah metode kualitatif distribusional dengan menggunakan kajian sintaksis dan semantik. Dalam metode distribusional terdapat salah satu teknik yaitu teknik substitusi. Substitusi merupakan teknik yang digunakan untuk membandingkan makna konjungsi "to" dan "tara" yang terdapat dalam drama Okuribito karya Yojiro Takita. Sumber data yang digunakan dalam penelitian ini adalah drama Okuribito. Drama Jepang ini 
diproduksi tahun 2008 oleh sutradara Yojiro Takita.. Penulis memilih drama ini sebagai sumber data karena dalam drama ini terdapat banyak ungkapan Jouken Hyougen dengan konjungsi "to" dan "tara" . Kemudian data dianalisis dengan tahapan-tahapan sebagai berikut:

1. Mengklasifikasikan data sesuai dengan dapat atau tidak dapat disubstitusikan, dengan cara dikonfirmasikan dengan Native Speaker.

2. Menganalisis struktur kalimat dengan konjungsi "to" atau "tara" sebagai acuan dalam menganalisis makna gramatikalnya.

3. Menganalisis makna gramatikal konjungsi "to" atau "tara" didasarkan pada predikat kalimat.

4. Melakukan substitusi konjungsi "to" dengan "tara" atau sebaliknya disesuaikan dengan gramatikalnya.

5. Menganalisis makna gramatikal konjungsi "to" atau "tara" setelah disubstitusikan.

6. Memaparkan hasil analisis secara deskriptif.

\section{HASIL DAN PEMBAHASAN}

Data yang diambil dalam penelitian ini diambil dari tuturan yang terdapat ungkapan kalimat pengandaian atau Jouken Hyougen dengan konjungsi "to" dan "tara" dalam drama Okuribito karya Yojiro Takita. Kemudian penulis mengklasifikasikan dan menganalisis data tersebut berdasarkan dapat atau tidak dapat konjungsi "to" dan "tara" disubstitusikan.

\section{Juoken hyougen dengan konjungsi "to" dan "tara" yang dapat disubstitusikan.}

Berdasarkan makna gramatikalnya kalimat pengandaian dengan konjungsi "to" dan "tara" yang dapat disubstitusikan, dibagi menjadi 5 bagian yaitu menyatakan suatu kejadian yang dianggap pasti dan umum terjadi atau kakugen （確言）, kebiasaan berdasarkan urutan waktu atau shuukan（習慣）, harapan atau ganbou (願望), pendapat/ pemikiran atau hatsugen-shikou（発言・思考）, kejadian lampau yang terjadi secara bersamaan seperti suatu ketetapan atau kakutei jouken（確 定条件）。 


\subsection{Menyatakan kejadian yang dianggap pasti dan umum terjadi atau kakugen (確言) .}

Kalimat 3 (okuribito $\rightarrow 00: 15: 45$ )

(3) お母さんが残してくれたお家だったら、家賃も要らないんでしょ。 Okaasan ga nokoshitekureta louchi / dattara/yachin mo /iranaindesho. $\overline{\text { (modifikator) }}(\overline{N) \text { (konj.tara) }} \overline{(N)} \overline{\text { (predikat) }}$

'Kalau tinggal di rumah peninggalan ibu, kan tidak perlu menyewa rumah'.

Kalimat (3) dilihat dari segi struktur sintaksisnya (kouzoujou), kalimat (3) merupakan kalimat kompleks/ majemuk atau fukubun yang terdiri dari dua klausa yaitu anak kalimat atau juuzokusetsu $(X)$ dan induk kalimat atau shusetsu (Y). Pada juuzokusetsu $(X)$ yaitu お母さんが残したくれたお家だったら (okaasan ga nokoshite kureta ouchi dattara) struktur sintaksisnya terdiri dari modifikator (okaasan ga nokoshitekureta), nomina (ouchi) dan konjungsi "tara", karena "tara" melekat pada kata benda secara gramatikal menjadi ouchi dattara. Adapun tuturan pada juuzokusetsu (X) mempunyai makna 'Kalau tinggal di rumah peninggalan ibu'. Shusetsu (Y) yaitu 家賃も要らないんでしょ (yachin mo iranaindesho) secara sintaksisnya terdiri dari nomina (yachin mo) dan predikat (iranaindesho). Predikat tersebut berupa kata kerja untuk menyatakan sesuatu yang dianggap pasti atau kakugen (確言) . Hal tersebut terlihat pada bentuk ungkapan yang melekat pada kata kerja yaitu desho (でしょ). Adapun tuturan pada shusetsu ( $Y$ ) mempunyai makna 'tidak perlu menyewa rumah kan'. Kalimat (3) menunjukkan suatu kejadian yang umum terjadi atau kakugen ( 確言 ) . Kemudian dilakukan substitusi konjungsi "tara" dengan konjungsi "to" sebagai berikut:

\section{3.a 亦さんが残してくれてお家だったら、家賃も要らないんでしょ。}

$(Y)$

Okaasan ga nokoshite kureta ouchi dattara, yachin mo iranaindeshou.

'Kalau tinggal di rumah peninggalan ibu, kan tidak perlu sewa rumah'. 


\section{お母さんが残してくれてお家だと、家賃も要らないんでしょ。}

$(X)$

$(Y)$

Okaasan ga nokoshite kureta ouchi dato, yachin mo iranaindeshou.

'Kalau disini tutup, akan membuat pengunjung sekarang bingung'.

Setelah disubstitusi dengan konjungsi "to", anak kalimat atau juuzokusetsu

$(X) \quad$ secara gramatikal dapat disubstitusikan, yaitu " ouchi dato " seperti yang terlihat pada kalimat (3.b). Selain itu, dilihat dari segi makna gramatikal konjungsi "to" dapat disubstitusikan, karena pada kalimat tersebut tidak mengalami perubahan makna. Shusetsu $(Y)$ predikatnya berupa kata kerja yang menyatakan sesuatu yang dianggap pasti atau kakugen (確言). Hal tersebut terlihat pada bentuk ungkapan yang melekat pada kata kerja yaitu desho (でしょ). Sehingga pada kalimat (3) dapat disimpulkan konjungsi "to" dan "tara" dapat digunakan untuk menyatakan suatu kejadian yang dianggap pasti dan umum terjadi atau kakugen (確言) .

\subsection{Menyatakan suatu kebiasaan berdasarkan urutan waktu atau shuukan （習慣）.}

Kalimat 4 (Okuribito $\rightarrow$ 00:30:42)

(4)お支度が整いましたら、お化粧を施す前に、お顔そりをいたします。 Oshitaku ga / totonoimashitara / okeshou o hodokosu maeni /okaosori o / itashimasu. (nomina) $\quad(V+$ tara $) \quad$ (klausa tambahan) (predikat)

'Kalau persiapannya sudah selesai, sebelum melakukan make up, mencukur (kumis, jenggot)'.

Kalimat (4) dilihat dari segi struktur sintaksisnya (kouzoujou), kalimat (4) merupakan kalimat majemuk atau fukubun yang terdiri dari tiga klausa yaitu anak kalimat atau juuzokusetsu $(X)$, klausa pelengkap dan induk kalimat atau shusetsu (Y). Pada juuzokusetsu $(X)$ yaitu お支度が整いましたら (oshitaku ga totonoimaishitara) struktur sintaksisnya terdiri dari nomina (oshitaku) dan verba yang diikuti konjungsi "tara" (tonoimashitara). Adapun tuturan pada juuzokusetsu $(X)$ mempunyai makna 'kalau persiapannya sudah selesai'. Kemudian kalusa 
Siswoyo, Analisis Makna Gramatikal Jouken Hyougen To dan Tara dalam Drama Okuribito

tambahan お化粧を施す前に (okeshou o hodokosu maeni) klausa tersebut tidak dibahas penulis karena fungsinya hanya sebagai tambahan saja yaitu urutan kegiatan berikutnya. Shusetsu (Y) yaitu お顔そりをいたします (okaosori o itashimasu) secara sintaksisnya terdiri dari nomina (okao) dan predikat (itashimasu). Predikat tersebut merupakan kata kerja yang digunakan untuk suatu pernyataan atau deklaratif. Adapun tuturan pada shusetsu $(Y)$ mempunyai makna 'mencukur kumis dan jenggot'. Kalimat (4) merupakan kalimat yang menyatakan suatu kejadian yang berulang-ulang atau kebiasaan berdasarkan urutan waktu shuukan (習慣) . Kemudian dilakukan substitusi konjungsi “tara” dengan konjungsi "to" sebagai berikut :

\section{4.a お支度が整いましたら、お化粧を施す前に、お顔そりをいたします。}

Oshitaku ga totonoimashitara,okeshou o hodokosu maeni, okaosori o itashimasu. 'Kalau persiapannya sudah selesai, sebelum melakukan make up, mencukur (kumis, jenggot)'.

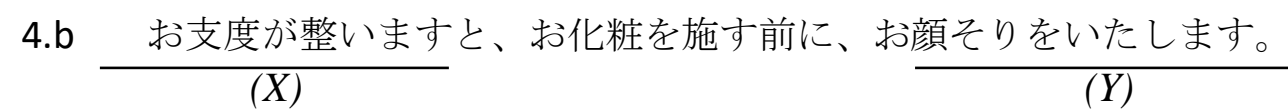

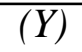

Oshitaku ga totonoimasuto, okeshou o hodokosu maeni, okaosori o itashimasu.

'Kalau persiapannya sudah selesai, sebelum melakukan make up, mencukur (kumis, jenggot)'.

Setelah disubstitusi dengan konjungsi "to", anak kalimat atau juuzokusetsu secara gramatikal dapat disubstitusikan, meskipun menggunakan verba bentuk masu ( ま す形) yaitu “totonoimasuto” seperti yang terlihat pada kalimat (4.b).

Selain itu, dilihat dari segi makna gramatikal konjungsi "to" juga dapat menggantikan, karena tidak mengalami perubahan makna pada kalimat tersebut, yaitu shusetsu $(Y)$ predikatnya berupa kata kerja yang digunakan untuk suatu pernyataan atau deklaratif yaitu itashimasu (いたします). Secara makna gramatikal kalimat tersebut menunjukkan makna suatu kejadian yang berulangulang atau kebiasaan berdasarkan urutan waktu atau shuukan (習慣). Sehingga pada kalimat (4) dapat disimpulkan konjungsi "to" dan "tara” dapat digunakan 
dalam kalimat pengandaian menunjukkan makna suatu kejadian yang berulangulang atau kebiasaan berdasarkan urutan waktu atau shuukan (習慣).

\subsection{Menyatakan suatu harapan atau ganbou（願望）。}

Kalimat 5 (Okuribito $\rightarrow$ 00:39:34)

（5）あんなできのいい息子がおったらの。 Anna dekino ii musuko ga ottarano (modifikator) (nomina) (V+tara)

'Seandainya punya anak laki-laki yang pintar seperti itu ya'.

Kalimat (5) dilihat dari segi struktur sintaksisnya (kouzoujou), kalimat (5) merupakan kalimat tunggal yang terdiri dari subjek（主語） dan predikat（述語）. Subjek あんなできのいい息子 (anna dekino iimusuko) terdiri dari modifikator atau penjelas subjek (anna deki no ii) yang melekat nomina (musuko). Kemudian predikat おったらの (ottara no) terdiri dari verba (oru) dan konjungsi “tara” yang diikuti $の($ tara no). Predikat dalam kalimat tersebut merupakan bentuk retoris yang menyatakan suatu harapan atau ganbou (願望). Hal tersebut terlihat pada ungkapan yang digunakan yaitu tara no (たらの). Akhiran の merupakan dialek atau hougen (方言) suatu daerah, sedangkan bentuk bakunya adalah 〜たらいいで す ね (---tara iidesune). Kalimat (5) merupakan kalimat tunggal yang menunjukkan suatu harapan atau ganbou （願望）. Adapun kalimat tersebut mempunyai makna 'seandainya punya anak laki-laki yang pintar seperti itu ya'. Sehingga makna gramatikal konjungsi "tara" kalimat tersebut menujukkan makna suatu harapan atau ganbou (願望). Kemudian dilakukan substitusi konjungsi “tara” dengan konjungsi "to" sebagai berikut:

5.a あんなできのいい息子がおったらの。

(kalimat tunggal)

Anna deki no ii musuko ga ottarano

'Seandainya punya anak laki-laki yang pintar seperti itu ya'.

5.b あんなできのいい息子がおるとの。

(kalimat tunggal)

Anna deki no ii musuko ga oruto no.

'Seandainya punya anak laki-laki yang pintar seperti itu ya'. 
Siswoyo, Analisis Makna Gramatikal Jouken Hyougen To dan Tara dalam Drama Okuribito

Setelah disubstitusi dengan konjungsi “to", kalimat tersebut secara gramatikal dapat disubstitusikan yaitu verba diubah dalam bentuk kamus atau jisho $k e i$, seperti yang terlihat pada kalimat (5.b). Selain itu, dilihat dari segi makna gramatikal konjungsi “to” juga dapat disubstitusikan, karena tidak mengalami perubahan makna pada kalimat tersebut. Secara makna gramatikal kalimat tersebut merupakan kalimat tunggal yang menunjukkan suatu harapan atau ganbou（願望）. Sehingga pada kalimat (5) dapat disimpulkan konjungsi "to" dan "tara” dapat digunakan dalam kalimat pengandaian menunjukkan makna suatu harapan atau ganbou（願望）.

\subsection{Menyatakan suatu pendapat/ pemikiran atau hatsugen-shikou (発言・ 思考）。}

Kalimat 6 ( Okuribito $\rightarrow 00: 43: 34$ )

(6) そう思ったら、なぜかチェロが弾きたくなった。

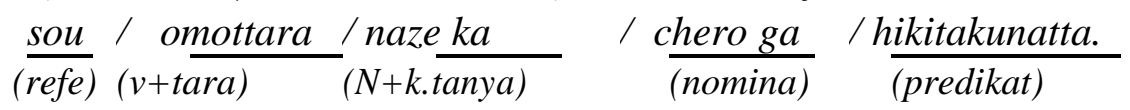

'Kalau dipikir-pikir, kenapa ya saya ingin menjadi pemain biola'.

Kalimat (6) dilihat dari segi struktur sintaksisnya (kouzoujou), kalimat (6) merupakan kalimat majemuk atau fukubun yang terdiri dari dua klausa yaitu anak kalimat atau juuzokusetsu (X) dan induk kalimat atau shusetsu (Y). Pada juuzokusetsu $(X)$ yaitu そう思ったら (sou omottara) struktur sintaksisnya terdiri dari reference atau kata yang merujuk (sou) dan verba yang diikuti konjungsi "tara" (omottara). Adapun kalimat pada juuzokusetsu $(X)$ mempunyai makna 'Kalau dipikir-pikir'. Ungkapan tersebut terdapat di awal kalimat yang digunakan untuk menentukan suatu pemikiran atau shikou（思考）. Shusetsu $(Y)$ yaitu なぜかチェロ が弾きたくなった (naze ka chero ga hikitakunatta) secara sintaksisnya berupa nomina yang diikuti kata tanya (naze ka), nomina (chero ga) dan predikat (hikitakunatta). Predikat tersebut berupa kata kerja bentuk lampau atau kakokei （過去形）. Adapun kalimat pada shusetsu (Y) mempunyai makna 'kenapa ya saya ingin menjadi pemain biola'. Kalimat (6) merupakan kalimat yang menyatakan suatu pemikiran atau shikou (思考) pada awal kalimat yang diikuti oleh hasil atau pengembangan pemikiran atau kanten （観点） pada klausa berikutnya. Sehingga 
makna gramatikal konjungsi "tara” kalimat tersebut adalah ungkapan pada awal kalimat pengandaian atau maeoki (前置き) diikuti dengan kalimat yang menunjukkan suatu pendapat atau pemikiran （発言・思考.

Kemudian dilakukan substitusi konjungsi "tara" dengan konjungsi "to" sebagai berikut :

6.a そう思ったら、なぜかチェロが弾きたくなった。

(X) (Y)

Sou omottara, naze ka chero ga hikitakunatta.

'Kalau dipikir-pikir, kenapa ya saya ingin menjadi pemain biola'.

6.bそう思うと、

Sou omouto, naze ka chero ga hikitakunatta.

'Kalau dipikir-pikir, kenapa ya saya ingin menjadi pemain biola'.

Setelah disubstitusi dengan konjungsi “to”, anak kalimat atau juuzokusetsu secara gramatikal dapat disubstitusikan, yaitu "omouto" seperti yang terlihat pada kalimat (6.b). Selain itu, dilihat dari segi makna gramatikal konjungsi "to" juga dapat disubstitusikan, karena tidak mengalami perubahan makna pada kalimat tersebut. Juuzokusetsu (X) merupakan ungkapan pada awal kalimat atau maeoki (前置き) diikuti dengan kalimat yang menunjukkan suatu pendapat/ pemikiran atau hatsugen-shikou (発言・思考) . Pada shusetsu $(Y)$ berupa kejadian yang sudah terjadi, hal ini terlihat pada predikatnya yaitu berupa kata kerja bentuk lampau kakokei (過去形. Sehingga pada kalimat (6) dapat disimpulkan konjungsi “to" dan “tara” dapat digunakan untuk ungkapan pada awal kalimat atau maeoki (前置き) diikuti dengan kalimat yang menunjukkan suatu pendapat / pemikiran atau hatsugen-shikou（発言・思考）.

\subsection{Menyatakan suatu kejadian yang terjadi bersamaan seperti suatu} ketetapan atau kakutei jouken（確定条件）.

Kalimat 7 (Okuribito $\rightarrow$ 01:55:27)

（7）今朝、来て見たら、突然死んでただよ。

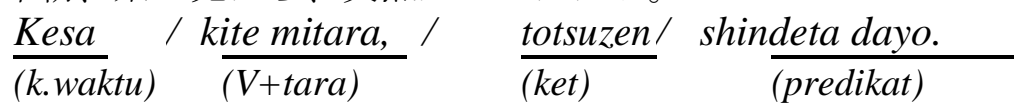

'Tadi pagi, ketika datang, sudah dalam keadaan meninggal'. 
Kalimat (7) dilihat dari segi struktur sintaksisnya (kouzoujou), kalimat (7) merupakan kalimat majemuk atau fukubun yang terdiri dari dua klausa yaitu anak kalimat atau juuzokusetsu $(X)$ dan induk kalimat atau shusetsu (Y). Pada juuzokusetsu $(X)$ yaitu 今朝、来て見たら (kesa, kite mitara) struktur sintaksisnya terdiri dari keterangan waktu (kesa) dan kata kerja atau verba yang diikuti konjungsi tara (kite mitara). Adapun kalimat pada juuzokusetsu (X) mempunyai makna seperti urutan kejadian 'tadi pagi, ketika datang'. Shusetsu $(Y)$ yaitu 突然死 んでただよ (totsuzen shindeta dayo) struktur sintaksisnya hanya berupa kata keterangan cara (totsuzen) dan predikat atau verba (shindeta yo). Predikat tersebut berupa kata kerja bentuk lampau (kako kei), jika dilihat hubungan antar kalimat shusetsu (Y) seolah-olah seperti suatu ketetapan atau kakutei jouken（確定条件）. Adapun kalimat pada shusetsu $(Y)$ mempunyai makna 'sudah dalam keadaan meninggal‘. Kalimat (7) menunjukkan kejadian lampau yang terjadi secara bersamaan seperti suatu ketetapan atau kakutei jouken (確定条件) . Kemudian dilakukan substitusi konjungsi "tara" dengan konjungsi "to" sebagai berikut :

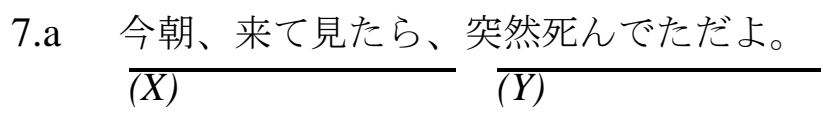

Kesa, kite mitara, totsuzen shindeta dayo.

'Tadi pagi, ketika datang, sudah dalam keadaan meninggal'.

$7 . b$ 今朝、来て見ると、突然死んでただよ。

$\overline{(X)} \overline{(Y)}$

Kesa, kite miruto, totsuzen shindeta dayo.

'Tadi pagi, ketika datang, sudah dalam keadaan meninggal'.

Setelah disubstitusi dengan konjungsi “to”, anak kalimat atau juuzokusetsu

$(X) \quad$ secara gramatikal dapat disubstitusikan, yaitu "kite miruto" seperti yang terlihat pada kalimat (10.b). Selain itu, dilihat dari segi makna gramatikal konjungsi "tara" juga dapat disubstitusikan, karena tidak mengalami perubahan makna pada kalimat tersebut. Shusetsu $(Y)$ predikat tersebut berupa kata kerja bentuk lampau (kako kei), jika dilihat hubungan antar kalimat shusetsu $(Y)$ seolah-olah seperti suatu ketetapan atau kakutei jouken (確定条件). Sehingga pada kalimat (7) dapat disimpulkan konjungsi "to" dan "tara” dapat digunakan dalam makna kondisional 
lampau diikuti kejadian yang seolah-olah seperti suatu ketetapan atau kakutei jouken（確定条件）.

\section{Juoken hyougen "to" dan "tara" yang tidak dapat disubstitusikan.}

Berdasarkan makna gramatikalnya kalimat pengandaian dengan konjungsi "to" dan "tara" yang tidak dapat disubstitusikan, dibagi menjadi 6 bagian yaitu menyatakan dugaan terhadap suatu hal atau gaigen ( 概言), ijin atau kyoka (許 可）, permohonan atau irai ( 依 頼) , ekspresi/ tindakan atau shutsugenbatarakigake（出現・働きがけ）， maksud atau ishi （意志）， saran diikuti dengan kata tanya atau toikake（問いかけ）。

\subsection{Menyatakan suatu dugaan terhadap suatu hal atau gaigen（ 概言） •}

Kalimat 8 (Okuribito $\rightarrow 00: 12: 56$ )

(8) 100 万ぐらいだったら、ウェブデザインの仕事でなんとか稼げる。 $\frac{100 \text { man gurai / dattara }}{\text { (nomina) }}$ (konj.tara) $\frac{\text { / webudezain no shigoto de / nantoka kasegeru. }}{\text { (ket.cara) }}$ 'Seandainya punya uang kira-kira1 juta yen, dengan bekerja sebagai desain website akan menghasilkan'.

Kalimat (8) dilihat dari segi struktur sintaksisnya (kouzoujou), kalimat (8) merupakan kalimat majemuk atau fukubun yang terdiri dari dua klausa yaitu anak kalimat atau juuzokusetsu $(X)$ dan induk kalimat atau shusetsu (Y). Pada juuzokusetsu (X) yaitu 100 万ぐらいだったら (hyaku man gurai dattara) struktur sintaksisnya berupa nomina (100 man gurai) dan konjungsi "tara" , karena konjungsi "tara" melekat pada kata benda secara gramatikal menjadi 100 man gurai dattara. Adapun kalimat pada juuzokusetsu $(X)$ mempunyai makna 'Seandainya punya uang kira-kiral juta yen’. Shusetsu $(Y)$ yaitu ウェブデザインの仕事でなんとか稼げる (webudezain no shigoto de nantoka kasegeru) secara sintaksisnya berupa keterangan cara (webudesain no shigoto de) dan predikat (nantoka kasegeru). Predikat tersebut berupa kata kerja yang menunjukkan suatu dugaan atau kemungkinan terhadap sesuatu hal atau gaigen ( 概言 ) , hal ini terlihat pada kata yang melekat sebelum verba yaitu nantoka (なんとか). Kata tersebut digunakan untuk menyatakan suatu yang bersifat subjektif atau kemungkinan terhadap suatu hal yang belum pasti kebenarannya. Adapun kalimat pada shusetsu $(Y)$ mempunyai makna yaitu 'dengan bekerja sebagai 
Siswoyo, Analisis Makna Gramatikal Jouken Hyougen To dan Tara dalam Drama Okuribito

desain website akan menghasilkan'. Jadi, makna gramatikal konjungsi “tara” pada kalimat (8) adalah makna kondisional tidak nyata atau hanjijitsu (反事実) yang menunjukkan suatu dugaan terhadap sesuatu hal atau gaigen ( 概言 ). Kemudian dilakukan substitusi konjungsi “tara” dengan konjungsi “to” sebagai berikut :

8.a 100 万ぐらいだったら、ウェブデザインの仕事でなんとか稼げる。

$(X)$ $(Y)$

100 man gurai dattara, webudezain no shigoto de nantonaku kasegeru. 'Kalau kirakira punya uang 1 juta yen, dengan bekerja website desain sudah cukup'.

8.b*100万ぐらいだと、ウェブデザインの仕事でなんとか稼げる。

(X) (Y)

100 man gurai dato, webudezain no shigoto de nantonaku kasegeru. 'Kalau kirakira punya uang 1 juta yen, dengan bekerja website desain sudah cukup'.

Setelah disubstitusi dengan konjungsi “to”, anak kalimat atau juuzokusetsu

(X) secara gramatikal dapat disubstitusikan, yaitu "100 man gurai dato” seperti yang terlihat pada kalimat (8.b). Sedangkan dilihat dari segi makna gramatikal konjungsi “to" tidak dapat disubstitusikan, karena pada kalimat (8) shusetsu (Y) predikatnya berupa kata kerja yang menunjukkan suatu dugaan atau kemungkinan terhadap sesuatu hal atau gaigen ( 概言 ) atau perkiraan yang belum pasti kebenarannya atau hanjijitsu (反事実) .Hal tersebut terlihat pada kata yang melekat sebelum verba yaitu nantoka. Kata tersebut digunakan untuk menyatakan suatu yang bersifat subjektif atau kemungkinan terhadap suatu hal yang belum pasti kebenarannya. Sehingga kalimat (8) dapat disimpulkan konjungsi "to" tidak dapat disubstitusikan dalam makna kondisional tidak nyata atau hanjijitsu (反事実) yang menunjukkan suatu dugaan atau kemungkinan terhadap sesuatu hal atau gaigen ( 概言) .

\subsection{Menyatakan suatu izin/saran atau kyoka（許可）.}

Kalimat 9 (Okuribito $\rightarrow$ 00:22:10)

（9）向いてないと思ったら、辞めりやいいさ。

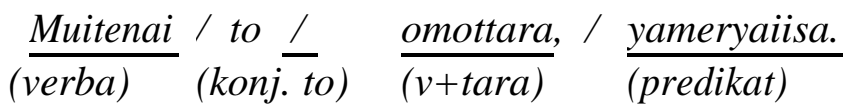

'Kalau dikira tidak sesuai, berhenti saja'. 
Kalimat (9) dilihat dari segi struktur sintaksisnya (kouzoujou), kalimat (9) merupakan kalimat majemuk atau fukubun yang terdiri dari dua klausa yaitu anak kalimat atau juuzokusetsu $(X)$ dan induk kalimat atau shusetsu (Y). Pada juuzokusetsu $(X)$ yaitu 向いてないと思ったら (muitenai to omottara) struktur sintaksisnya terdiri dari verba (muitenai), konjungsi (to) ,verba yang diikuti konjungsi "tara" (omottara). Adapun kalimat pada juuzokusetsu $(X)$ mempunyai makna 'kalau dikira tidak sesuai'. Shusetsu $(Y)$ yaitu 辞 めりやいいさ (yameryaiisa) secara sintaksisnya hanya berupa predikat (yameryaiisa). Predikat tersebut berupa kata kerja untuk menyatakan suatu perijinan atau kyoka（許可）, hal ini terlihat pada bentuk ungkapan yang melekat pada kata kerja yaitu りやいい さ (ryaiisa). Adapun kalimat pada shusetsu $(Y)$ mempunyai makna 'berhenti saja'. Kalimat (9) merupakan menunjukkan ungkapan pada awal kalimat atau mae oki (前置き) diikuti dengan kalimat yang menyatakan suatu perijinan atau kyoka （許可）. Kemudian dilakukan substitusi konjungsi “tara” dengan konjungsi "to" sebagai berikut :

9.a 向いてないと思ったら、辞めりやいいさ。

Muitenai to omottara, yameryaiisa.

'Kalau dikira tidak sesuai, berhenti saja'.

$9 . \mathrm{b}$ *向いてないと思うと、止めりやいいさ。

$(X) \quad(Y)$

Muitenai to omouto, yameryaiisa.

'Kalau dikira tidak sesuai, berhenti saja'.

Setelah disubstitusi dengan konjungsi “to", anak kalimat atau juuzokusetsu $(X)$ secara gramatikal dapat disubstitusikan, yaitu "omouto" seperti yang terlihat pada kalimat (9.b). Sedangkan dilihat dari segi makna gramatikal konjungsi “to" tidak dapat disubstitusikan, karena pada kalimat (9) shusetsu (Y) predikatnya berupa kata kerja yang menunjukkan suatu ijin atau saran, hal ini terlihat pada kata yang melekat sebelum verba yaitu ryaiisa. Kata tersebut digunakan untuk menyatakan suatu ijin atau saran yang terdapat unsur subjektif. Dari kalimat (9) dapat disimpulkan konjungsi "to" tidak dapat digunakan dalam kalimat pengandaian yang menunjukkan suatu ijin atau kyoka（許可）. 


\subsection{Menyatakan suatu permohonan atau irai（依頼） •}

Kalimat 10 (Okuribito $\rightarrow$ 00:56:50)

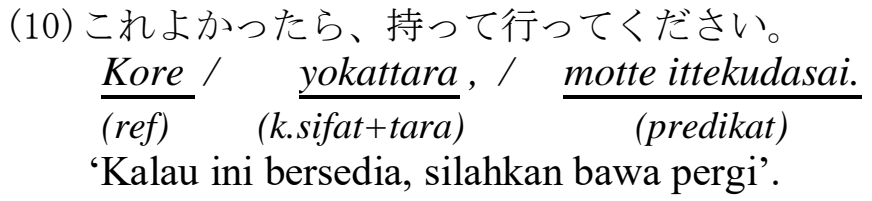

Kalimat (10) dilihat dari segi struktur sintaksisnya (kouzoujou), kalimat (10) merupakan kalimat majemuk atau fukubun yang terdiri dari dua klausa yaitu anak kalimat atau juuzokusetsu $(X)$ dan induk kalimat atau shusetsu (Y). Pada juuzokusetsu $(X)$ yaitu これよかったら (kore yokattara) struktur sintaksisnya terdiri dari reference atau kata tunjuk (kore) dan kata sifat (keiyoushi) yang diikuti konjungsi tara (yokattara). Adapun kalimat pada juuzokusetsu (X) mempunyai makna 'Kalau ini bersedia'. Shusetsu (Y) yaitu 持って行ってください (motte ittekudasai) secara sintaksisnya hanya berupa predikat (motteittekudasai). Predikat tersebut berupa kata kerja yang menyatakan permohonan kepada orang lain agar melakukan sesuatu atau irai （依頼）, hal ini terlihat pada bentuk ungkapan yang melekat pada kata kerja yaitu 〜てください (tekudasai). Adapun kalimat pada shusetsu (Y) mempunyai makna "Silahkan bawa pergi”. Kalimat (10) menunjukkan ungkapan pada awal kalimat atau mae oki (前置き) diikuti dengan kalimat yang menyatakan suatu permohonan atau irai (依頼). Kemudian dilakukan substitusi konjungsi "tara” dengan konjungsi "to” sebagai berikut :

10.aこれよかったら、持って行ってください。

Kore yokattara, motte ittekudasai.

'Kalau ini setuju, silahkan bawa pergi'.

$10 . b$ *これいいと、持って行ってください。

$(X) \quad(Y)$

Kore iito, motte ittekudasai.

'Kalau ini setuju, silahkan bawa pergi'.

Setelah disubstitusi dengan konjungsi “to”, anak kalimat atau juuzokusetsu (X) secara gramatikal dapat disubstitusikan, yaitu "iito” seperti pada kalimat 
(10.b). Sedangkan dilihat dari segi makna gramatikal konjungsi "to" tidak dapat disubstitusikan, karena pada kalimat (10) shusetsu $(Y)$ predikatnya berupa kata kerja yang menunjukkan suatu permohonan, hal ini terlihat pada kata yang melekat sebelum verba yaitu tekudasai. Kata tersebut digunakan untuk menyatakan suatu permohonan kepada orang lain agar melakukan sesuatu atau irai (依頼). Dari kalimat (10) dapat disimpulkan konjungsi "to" tidak dapat

digunakan untuk menunjukkan ungkapan pada awal kalimat atau mae oki (前置 き) diikuti dengan kalimat yang menyatakan suatu permohonan kepada orang lain agar melakukan sesuatu atau irai（依頼）.

\subsection{Menyatakan suatu ekspresi/ tindakan atau shutsugen-batarakigake}

\section{（出現・働きがけ）。}

Kalimat 11 (Okuribito $\rightarrow$ 01:03:03)

（11）でも...もし会ったら,ぶんなぐる。 $\frac{\text { demo }}{\text { (konj) }} / \frac{\text { moshi attara, }}{(\text { V+tara })} / \frac{\text { bun naguru. }}{\text { (predikat) }}$

'Tapi.. kalau ketemu, akan saya pukul dengan keras'.

Kalimat (10) dilihat dari segi struktur sintaksisnya (kouzoujou), kalimat (10) merupakan kalimat majemuk atau fukubun yang terdiri dari dua klausa yaitu anak kalimat atau juuzokusetsu $(X)$ dan induk kalimat atau shusetsu (Y). Pada juuzokusetsu (X) yaitu でも、もし会ったら (demo, moshi attara) struktur sintaksisnya terdiri dari konjungsi yang berfungsi sebagai penghubung atau setsuzokushi (demo) dan verba yang diikuti konjungsi moshi + "tara" (moshi attara). Adapun kalimat pada juuzokusetsu (X) mempunyai makna 'tapi.... kalau ketemu’. Shusetsu $(Y)$ yaitu ぶんなぐる (bun naguru) secara sintaksisnya berupa predikat (bun naguru). Predikat tersebut berupa kata kerja bentuk kamus atau jisho kei (辞書形) yang digunakan untuk menyatakan suatu ekspresi/ tindakan atau shutsugen-batarakigake（出現・働きがけ）. Adapun kalimat pada shusetsu (Y) mempunyai makna 'akan saya pukul dengan keras'. Kalimat (11) merupakan kalimat yang menyatakan suatu ekspresi/ tindakan atau shutsugen-batarakigake 
（出現・働きがけ）。Kemudian dilakukan substitusi konjungsi “tara” dengan konjungsi "to" sebagai berikut :

11.a でも....もし会ったら、 ぶんなぐる。

Demo...moshi attara, bunnaguru.

'Tapi ....kalau ketemu, akan saya pukul dengan keras'.

11.b * でも....もし会うと、 ぶんなぐる。

Demo...moshi auto, bunnaguru.

'Tapi ....kalau ketemu, akan saya pukul dengan keras'.

Setelah disubstitusi dengan konjungsi “to”, anak kalimat atau juuzokusetsu $(X)$ secara gramatikal dapat disubstitusikan, yaitu “demo..moshi auto” seperti yang terlihat pada kalimat (11.b). Sedangkan dilihat dari segi makna gramatikal konjungsi "to" tidak dapat disubstitusikan, karena pada kalimat (11) shusetsu (Y) predikatnya berupa kata kerja bentuk kamus atau jisho kei (辞書形) yang digunakan untuk menyatakan suatu ekspresi/ tindakan. Sehingga dari kalimat (11) dapat disimpulkan konjungsi "to" tidak dapat digunakan dalam kalimat pengandaian yang menunjukkan suatu ekspresi/ tindakan atau shutsugenbatarakigake（出現・働きがけ）。

\subsection{Menyatakan suatu maksud atau ishi（意志） •}

Kalimat 12

(Okuribito $\rightarrow$ 01:07:57)

(12) 私死んだら、この人にやってもらいたいと思った。

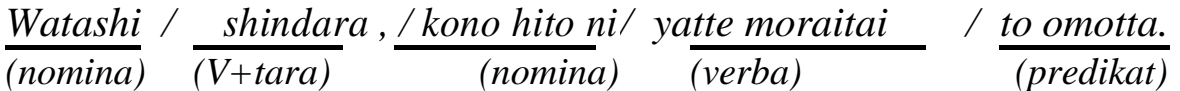

'Kalau saya meninggal, saya ingin orang ini yang mengkremasinya'.

Kalimat (12) dilihat dari segi struktur sintaksisnya (kouzoujou), kalimat (12) merupakan kalimat majemuk atau fukubun yang terdiri dari dua klausa yaitu anak kalimat atau juuzokusetsu $(X)$ dan induk kalimat atau shusetsu (Y). Pada juuzokusetsu $(X)$ yaitu 私死んだら(watashi shindara) struktur sintaksisnya terdiri dari nomina (watashi) dan verba yang diikuti konjungsi "tara" (shindara). Adapun kalimat pada juuzokusetsu (X) mempunyai makna 'Kalau saya 
meninggal'. Shusetsu $(Y)$ yaitu この人にやってもらいたいと思った (kono hito ni yatte moraitai to omotta) secara sintaksisnya berupa nomina (kono hito ni), verba (yatte moraitai) yang menunjukkan suatu keinginan atau ganbou (願望) dan predikat (to omotta) berupa verba yang menyatakan suatu maksud atau ishi (意 思）. Adapun kalimat pada shusetsu $(Y)$ mempunyai makna yaitu 'saya ingin orang ini yang melakukannya (kremasi)'. Jadi, makna gramatikal konjungsi “tara” pada kalimat (21) menunjukkan suatu maksud atau ishi （意思）. Kemudian dilakukan substitusi konjungsi “tara” dengan konjungsi "to" sebagai berikut :

\section{2.a 私死んだら、この人にやってもらいたいと思った。 \\ $(X) \quad(Y)$}

Watashi shindara, kono hito ni yatte moraitai to omotta.

'Kalau saya meninggal, saya ingin orang ini yang mengkremasinya'.

$12 . \mathrm{b} * \frac{\text { 私死と、 }}{(X)} \frac{\text { こ人にやってもらいたいと思った。 }}{(Y)}$

Watashi shinuto, kono hito ni yatte moraitai to omotta.

'Kalau saya meninggal, saya ingin orang ini yang mengkremasinya'.

Setelah disubstitusi dengan konjungsi “to”, anak kalimat atau juuzokusetsu(X) secara gramatikal dapat disubstitusikan, yaitu "watashi shinuto" seperti yang terlihat pada kalimat (12.b). Sedangkan dilihat dari segi makna gramatikal konjungsi "to" tidak dapat disubstitusikan, karena pada kalimat (12) shusetsu (Y) predikatnya berupa kata kerja yang menunjukkan suatu maksud atau ishi (意思) yaitu "to omotta". Sehinggga dari kalimat (12) dapat disimpulkan konjungsi "to" tidak dapat digunakan untuk makna kondisional bersyarat atau katei jouken（仮定条 件）yang menunjukkan suatu maksud atau ishi（意思）。

\subsection{Menyatakan suatu saran diikuti dengan kata tanya atau toikake} （問いかけ）。

Kalimat 13 (Okuribito $\rightarrow$ 01:52:48)

（13）会いたかったら、会いにいけばいいじゃないですか。 Aitakattara, / aini ikebaii janai desuka. (V+tara) (predikat) 'Kalau ingin ketemu, bukankah pergi untuk menemuinya itu bagus?' 
Kalimat (13) dilihat dari segi struktur sintaksisnya (kouzoujou), kalimat (13) merupakan kalimat majemuk atau fukubun yang terdiri dari dua klausa yaitu anak kalimat atau juuzokusetsu (X) dan induk kalimat atau shusetsu (Y). Pada juuzokusetsu $(X)$ yaitu 会いたかったら (aitakattara) struktur sintaksisnya berupa kata kerja bentuk keinginan diikuti konjungsi "tara” (aitakattara). Adapun kalimat pada juuzokusetsu $(X)$ mempunyai makna 'Kalau ingin ketemu'. Shusetsu $(Y)$ yaitu 会いにいけばいいじやないですか (aini ikebaii janaidesuka?) secara sintaksisnya berupa predikat atau kata kerja (aini ikebaii janaidesuka?). Predikat tersebut berupa kata kerja yang menyatakan suatu saran (アドバイス) yang dipertegas dengan menggunakan kata tanya（問いかけ）, hal ini terlihat pada bentuk ungkapan yang melekat pada kata kerja yaitu 〜いいじゃないですか (.....ii janaidesuka). Adapun kalimat pada shusetsu $(Y)$ mempunyai makna 'bukankah pergi untuk menemuinya itu bagus? '. Kalimat (13) merupakan kalimat yang menunjukkan suatu saran dengan menggunakan kata tanya atau toikake (問いかけ). Kemudian dilakukan substitusi konjungsi “tara” dengan konjungsi "to" sebagai berikut :

13.a 会いたかったら、会いにいけばいいじゃないですか。

Aitakattara, aini ikebaii janai desuka.

'Kalau ingin ketemu, bukankah pergi untuk menemuinya itu bagus?'

13.b*会いたいと、会いにいけばいいじゃないですか。

Aitaito, aini ikebaii janai desuka.

'Kalau ingin ketemu, bukankah pergi untuk menemuinya itu bagus?'

Setelah disubstitusi dengan konjungsi “to”, anak kalimat atau juuzokusetsu $(X)$ secara gramatikal dapat disubstitusikan, yaitu “aitaito” seperti pada kalimat (13.b). Sedangkan, dilihat dari segi makna gramatikal konjungsi "to" tidak dapat menggantikan, karena pada kalimat (13) shusetsu $(Y)$ predikatnya berupa kata kerja yang menunjukkan suatu saran atau adobaisu (アドバイス) yang dipertegas dengan menggunakan kata tanya atau toikake (問いかけ), hal ini terlihat pada bentuk ungkapan yang melekat pada kata kerja yaitu 〜いいじゃいですか (....ii janaidesuka). Dari kalimat (13) dapat disimpulkan konjungsi “to"tidak dapat 
digunakan dalam kalimat pengandaian yang menunjukkan suatu saran atau adobaisu（アドバイス） dengan menggunakan kata tanya atau toikake（問いかけ）。

\section{SIMPULAN}

Berdasarkan hasil penelitian dari tuturan-tuturan yang terdapat konjungsi "to" dan "tara" dalam drama Okuribito, penulis menemukan bahwa kedua konjungsi tersebut, sesuai dengan makna gramatikalnya ada yang dapat disubstitusikan dan ada juga yang tidak dapat disubstitusikan. Adapun pengklasifikasian makna gramatikalnya adalah sebagai berikut:

1. Makna gramatikal konjungsi "to" dan "tara" yang dapat disubstitusikan:

a. Menyatakan kejadian yang dianggap pasti dan umum terjadi atau kakugen

b. (確言).

c. Menyatakan kebiasaan berdasarkan urutan waktu atau shuukan（習慣）.

d. Menyatakan harapan atau ganbou（願望）.

e. Menyatakan pendapat/ pemikiran atau hatsugen-shikou（発言・思考）.e. Menyatakan kejadian lampau yang terjadi secara bersamaan seperti suatu

f. ketetapan atau kakutei jouken（確定条件）.

2. Makna Gramatikal konjungsi "to" dan "tara" yang tidak dapat disubstitusikan

a. Menyatakan dugaan terhadap suatu hal atau gaigen ( 概言) .

b. Menyatakan ijin atau kyoka (許可).

c. Menyatakan permohonan atau irai (依頼).

d. Menyatakan ekspresi/ tindakan atau shutsugen-batarakigake（出現・働きが け).

e. Menyatakan maksud atau ishi (意志).

f. Menyatakan saran diikuti dengan kata tanya atau toikake（問いかけ）

\section{REFERENSI}

AOTS. (1989). Shin Nihongo No Kiso I. Japan: Artizan.

Azizah, Suci Siti. (2008). Analisis Konstrastif Ungkapan Pengandaian Bahasa Jepang dan Bahasa Indonesia.

Etsuko.Tomomatsu. (2000). Donna toki dou tsukau nihongo hyougen bunkei 200.Tokyo: Aruku.

Guruupu Jamashi. (1998). Nihongo Bunkei Jiten. Japan: Kuroshio.

Kridalaksana, Harimurti. (1983). Kamus linguistik. Jakarta: PT Gramedia.

Matsumoto, fushiko. Hoshino, Muko. (1992). Nihongo Nouryoku Shiken. Tokyo:

UNICOM. 
Matsuoka. (2000). Shokyu wo oshieru hito no tame no nihongo bunpo hando bokku. Tokyo: Kabushiki kaisha surie network.

Matsura, Kenji. (1994). Kamus Bahasa Jepang-Indonesia. Kyoto: Kyoto sangyo University Press.

Soeparno. (2002). Dasar-dasar linguistik umum. Yogyakarta: Tiara Wacana.

Sudjianto. Dahidi, Ahmad. (2004). Pengantar linguistik Bahasa Jepang. Jakarta: Kesaint blanc.

Sunagawa. (1998). Shokyuu o Oshieru Nihongo bunkei jiten. Tokyo: Kuroshio.

Sutedi, Dedi. (2004). Dasar-dasar Linguistik Bahasa Jepang. Bandung: Humaniora Utama Press.

Suzuki, Shinrou. (1998). Goukaku suijun nihongo kyoushi nouryouku kentei shiken yougoshu. Tokyo: ARC Academy.

Tanaka, yone. (2002). Minna No Nihongo (Shokyuu I). Surabaya: PT. Pustaka Lintas Budaya. Seri A Network.

http://pbj.umy.ac.id/pembelajar-bahasa-jepang-di-indonesia-terbesar-kedua-didunia/ (Diunduh 3 september 2014)

http://respository.upi.edu/operator/upload/s.c0551.034401_chapter2.pdf. (Diunduh 10 september 2014) 